Over and above his arduous medical commitments, Aitken found time to serve as a magistrate.

\section{DONALD ERIC BROADBENT, formerly member of the Medical Research Council's external stafi at the Department of Experimental Psychology, Oxford}

Donald Broadbent, who died on 10 April 1993, aged 66 , was recognised, nationally and internationally, as a major figure in applied experimental psychology. He was educated at Winchester and Pembroke College, Cambridge and in between the two he served in the RAF. His career began to take shape, however, when, in 1949, he joined the Medical Research Council's Applied Psychology Unit and was able to direct his considerable talents to the pressing psychological problems which emerged as a concomitant of living in an industrial society. He began with the study of the effects of noise on performance efficiency, and the techniques he originated were applied also to the ways in which attention and cognitive function developed. He was the author of innumerable scientific papers and books, perhaps the most important of which was his first, Perception and Communication, published in 1958.

In 1958, Broadbent was appointed director of the Applied Psychology Unit at Cambridge, a unit which, due to his leadership, earned worldwide recognition. Then, in 1974, he moved to an analogous unit at Oxford where, as a member of the Medical Research Council's external staff, he was relieved of a great deal of administrative and committee work and so able to devote more of his time and energy to research.

Broadbent's achievements were duly recognised: he was appointed CBE in 1974 and he received doctorates from several universities in England and abroad. In 1968 he was elected to the fellowship of the Royal Society, and in 1985 to the honorary fellowship of our College.

If a suitable epitaph to Broadbent's memory were to be sought nothing better could be found than his own dictum: "The test of intellectual excellence of a psychological theory, as well as its moral justification, lies in its application to concrete practical considerations."

\section{Mohsen SOHbi NaGuIB, Senior Lecturer in Psychiatry and Honorary Consultant Psychiatrist at St Mary's Hospital and St Charles Hospital, London}

Mohen Naguib died suddenly on 12 February 1993 at the age of 43. He studied medicine at Ain Shams University, Cairo, where he graduated MB BCh in 1974. He pursued an early interest in psychiatry at the Behman Hospital, Cairo, and later came to the UK for postgraduate training at the Maudsley where he was in due course appointed senior registrar, becoming in
1982 a lecturer in the Institute of Psychiatry. In that year he gained the DPM and was elected MRCPsych.

He was a dedicated research worker, particularly into the psychiatry of old age, as witness his several highly esteemed contributions to the literature of the subject. Naguib's early death robs psychiatry of not only an established research worker but of an excellent teacher at both undergraduate and postgraduate levels. He took a keen interest in College affairs and had recently been appointed a member of the Central Approval Panel as convenor from the Chiltern and Thames Valley Division of visits to the Southern Division. Naguib was a devoted Christian and gave a good deal of his time to the Coptic Orthodox Church of St Mark, London.

$\mathrm{He}$ is survived by his wife, Noorah, and their two children.

A.F.S. TANAGHow

\section{ERIC DOUglas West, formerly Consultant Psychiatrist, Sutton Hospital, Sutton, Surrey}

Eric West who died on 13 November 1992, aged 73, was educated at local schools in the Sutton, Surrey area, but before he could complete his studies to university entrance level he enlisted in the Royal Artillery. In 1939, aged 20, by then a Staff Sergeant, he was a member of the ill-fated British Expeditionary Force and in the retreat to Dunkirk was captured by the Germans.

West used his long years of captivity to the best possible advantage: He studied German and to such good effect, indeed, that he was able to act as camp interpreter. It was perhaps his own suffering as a POW and that of his fellow prisoners that prompted his interest in medicine in general and in psychiatry in particular. He was liberated by the Americans in 1945.

After demobilisation, West gained additional academic qualifications in order to be admitted to medical school. This done, he entered St Thomas' Hospital where the glittering prizes he won as an undergraduate presaged his subsequent highly successful career: in 1949 he was awarded the Foord Caiger Exhibition in Pathology and in 1950 both the Wainwright Prize in Medicine and the BMA Essay Prize. He graduate MB BS London in 1951.

It was at St Thomas' that West came under the influence of Dr William Sargant, and there can be little doubt that he was instrumental in confirming West's choice of a specialty. The wisdom of his choice is reflected in the two further academic prizes he was to win: in 1958 he was awarded the Planck Prize in Psychiatry at St Thomas', and in 1960, the Gaskell Gold Medal, the most prestigious prize in British psychiatry.

After qualification, West was appointed registrar in neurology at St Thomas' where he became 